\title{
Progress and Barriers In Relation To Sustainable Development in Shell (Case Study of Shell Nigeria)
}

\author{
${ }^{1,2}$ Tsado, D.G., ${ }^{2}$ Adamu, M. and ${ }^{2}$ Aderinola, M.A. \\ ${ }^{I}$ Department of Chemical \& Process Engineering, Faculty of Engineering \& Physical Sciences, University of \\ Surrey, GU2 7XH, Guildford UK \\ ${ }^{2}$ Department of Chemical Engineering, The Federal Polytechnic, P.M.B 55, Bida. Niger State. Nigeria
}

\begin{abstract}
Nigeria accounts for about 16\% of the Shell's global oil business ventures, and about $7 \%$ of total profits. Shell has come across a wide range of sustainable development issues throughout its operations. Against this background, this study examines the performance (environmental and social) and efforts by Shell Nigeria in moving their operations in the way that promotes sustainability; and also looks into the hindrances to implementation of the practice of sustainability. The operational data and the company statements were used to access and explain the company's approach to sustainability. Shell's progress in this approach was evaluated and its performance were analysed from data on its social and environmental reports for seven years (2005 to 2011). The general approach of Shell indicates that it understands sustainability issues fronting it and the actions required to improve sustainable performance. Despite Shell's good progress in social and environmental performance over the years, as expressed in their annual sustainability reports, there still exist some challenges and worries particularly in the areas of oil spills, gas flaring and security in the Niger Delta.Among other obstacles, the operational spills in Nigeria have no significant environmental improvement over the years, and have contributed to the volume of global operational spills in Shell. It claims that $72 \%$ volume of the spills is from sabotage and theft, and the remaining percentage is due to its own operational failures and ageing facilities; but its 2011 report shows an outrageous oil spill due to its operations over the sabotage spill. Shell is encouraged to target long-term performance in sustainable development that is robust across economic, social, environmental and political spheres in Nigeria.
\end{abstract}

Key words:sustainability, Shell, Nigeria, environment, performance

\section{Introduction}

Progress towards sustainable development places a significant repute on the multinational oil and gas industries as the society frequently express disapproval to their line of attitudes towards sustainability matters (Lyuba, 2004). Public consciousness is on the increase on the consequences on the communities and environment as a result of the operations of these companies. Oil and gas industry is a complex industry with a supply chain that often cuts across multiple geographies, working within cultures to meet the world's energy demand. This energy is a source of heat, mobility, light, and communications for billions of people around the world (UNGCA, 2012).

The concept of sustainability has been defined as "meeting the needs of the present without compromising the ability of the future generations to meet their needs" (WCED, 1987). To the perspective of oil and gas industries, sustainability should mean to meet the people's need at a safe, low cost, and low environmental harms pending the availability of an appropriate alternative energy resource is put in place; and not to mean production sustenance of the energy sourcefor indefinite time (Lyn, 2003). In a nut shell, the various competitive needs of human needs have to be balanced economically, socially and environmentally in the domain of sustainable development (Sustainable Development Commission, 2011; WCED, 1987).

In other words, sustainable development can be seen by oil companies, firstly, in terms of concern on environment that results from the way and manner they operate. Their manner of industrial operations can lead to damages on the environment, for example, air, soil and water pollution, disruption of vegetation and wildlife, waste, and greenhouse harms. This environmental damage is the outcome of upstream activities, such as drilling in a dense biodiversity area, or downstream activities, such as refinery, where there are emissions and effluent discharges into air, ground or water (Frynas, 2009). Secondly, in terms of development which explains the big role private sector can play in poverty reduction and educational improvement through practices of social responsibility. Development is still an aspect of social problems which also includes health, human rights, safety, and issues relating to the harmful impacts of industrial activities on indigenous communities in developing countries (Jenkins, 2005). Innovations for alternative source of energy to reduce overdependence on the fossil fuels are also part of this development. Thirdly, in terms of governance which is divided into economic and political issues. In developing countries, exportation of natural resources can weaken their 
governance and political responsibility, and at the same time, brings about appreciation of currency exchange rate (Frynas, 2009; Sachs and Warner, 1999).

Royal Dutch Shell, a multinational oil and gas will be looked into. Shell is an international group of energy and petrochemical corporations that employs about 90,000 people in over 80 countries (Shell, 2011). Its goalis to contribute to meeting the energy demands of the society with regards economic, environmental and social constraints. The industry is comprises of three major sectors: exploration and production of oil and natural gas (upstream); refining, manufacturing, supplying and marketing of products and chemicals across the world (downstream); and schemes and technology, which alsomanages issues relating to sustainability.

\section{Sustainable Development in Shell}

Shell experiencesdifferent types of sustainability concerns in its activities: climate change; ecosystem services; local environmental impact, work force protections; product safety and environmental risks; process safety; local community and society; human rights; business morals and transparency; labour practice etc (Albert, 2011; IPECA, 2010).

There had been an outburst of international anger in the past over the controversy that surrounded the Shell's industrial activities, for example, the issue of Brent Spar when the British government, in 1995, gave its consent to Shell's request to dump into deep Atlantic waters (Shell International, 1995). The Brent Spar dispute and some other controversial issues have caused Shell to develop a focal approach or strategy towards sustainable development (Naimi, 2011).

\section{Shell's Approach to Sustainability}

Several approaches are used by Shell to stress its commitment to sustainable development in its operations and it is enshrined in the ways they manage their business. And this brands them as one of the top multinational corporations on its strategies towards sustainable development (Frynas, 2009). The approach or strategy needs to suite Shell's set of ecological, socio-cultural, economic and institutional conditions (Barry and Bass, 2002). These approaches are listed below and it covers the overall approach as talked by Shell; assessment of actual approach and evaluation of its conduct over time; and the performance evaluation internally and externally.

1 .

a. Business Principles: General Business Principles was developed by shell and it expects compliance by all its companies and corporate allies. The principles emphasis on strong financial foundation; free and fair competition; business honesty; political activities in the confines of law; values for health, safety, security and environment; local community responsibilities; communication and engagement of stakeholders; and laws and regulation compliance (Shell, 2011).

b. Code of Conducts: This is the setting of code of conducts, which is a standardthat regulates the behaviour of its employees in a way and manner that promotes sustainability values.

c. Code of Ethics: This belongs to decision-making managements with respect to its affairs of governance in the business.

d. Check line: disobedience to these conducts and ethics should be reported by stakeholders through a global help line.

e. Initiative Support: Shell gives backing for initiatives from human rights organisations, transparency groups, and other related NGOs that offer contributions towards sustainability.

2. These approaches are a set of standards and principles to Shell and are adopted in its operations or activities that promote and underpin, and not undermine, sustainable development.

3. Performance Evaluation: the performance on sustainability issues is monitored; bringing stakeholders into the picture of sustainable development is vital in Shell's approach towards sustainability matters. It engages relevant NGOs to evaluate the varying demands in society.

4. Sustainability Report: This is the progress made so far by shell and it has been in communication to the stakeholders on yearly basis since 1997, and the reports agrees with the Global Reporting Initiatives (GRI) that serves as an external guide. A six man team of autonomous professionals makes up an External Review Committeeto evaluate the sustainability report to know its significance and response to stakeholders.

\section{Sustainability Practice}

From 1995 till date there has been a change in Shell's strategy towards sustainable development. This change was declared by Phillip Watts, the former chairman of Shell, in light of the Brent Spar issue, and Niger Delta, Nigeria crisis that surround the killing of Ogoni leader, Ken Saro-Wiwa(Naimi, 2011). In 1996 Shell 
started its collaborations with stakeholders and different organisations, such as Amnesty International. Its business Principles were changed in 1997 to what it is today. Its first sustainability report was released in 1998.

A familiar case of Shell's strategy or approach towards sustainable development is in the case of Nigeria. This is where this paper will focus:"the progress and barriers in relation to sustainable development in Shell, Nigeria". The approach to sustainability in Shell global (discussed above) applies also to its operations in every of its companies all over the world. Shell, Nigeria is taken as a case study in this Essay.

\section{Shell Nigeria}

Nigeria accounts for about $16 \%$ of the Shell's global oil business ventures, and about $7 \%$ of total profits (Albert, 2011). This production it carries out from more than eighty fields. Shell operates both offshore and onshore whose activities in Nigeria is structured as a joint venture with other companies and the Nigerian National Petroleum Corporation (NNPC), and a 100\% Shell-owned companies. Its joint venture companies include the Shell Petroleum Development Company (SPDC), and Liquefied Natural Gas Limited (NLNG); while its $100 \%$ owned includes Shell Nigeria Exploration and Production Company (SNEPCO). The main damage of environment (such as oil spills and gas flares) arise from these companies in which, up till today, production of oil in Niger Delta Nigeriahas generated so serious conflicts that Shell had to close down some of its sites.

Outside North America, Shell's operation in Nigeria is considered to be its major and greatest complicated business ventures (Shell Dialogues, 2011). Despite its compliance to its sustainability approaches in Nigeria case it has not always been effective. While Brent Spar was an awakening call, Nigeria keeps Shell awake at all times. Shell not living up to expectation in its sustainability values in Nigeria case has made NGOs (e.g Amnesty, Living Earth Foundation etc) place a lot of emphasis on Nigeria. According to Wheeler et al. (2000), there are three things that drive corporate social responsibility (CSR) to reality: policy, economic and operations; but disconnection exists between them in the case of Shell. The Sustainability report, 2004 reveals Shell's commitment to CSR in Nigeria but has had little changes in its practices. Shell also has admitted that it has caused a lot of undesirable and unwarranted harm in its worldwide oil and gas activities (FOEI, 2011). Shell's performance and the progress made towards sustainable development over the years in their operations will be assessed.

\section{Performance, Progress and Barrier}

To evaluate Shell's progress in its approach towards sustainable development, its performance will be analysed from data on its social and environmental reports. The social and environmental performance data is gotten from Shell Sustainability Report 2011 that reveals the years 2002 to 2011.

\section{Environmental Performance:}

The components that are measured to evaluate Shell's environmental performance for seven years are presented as data in Table 1 below. It runs across many indicators under climate change, ecosystem services and local environmental impact. A summary of which is presented here, with emphasis on the ones that most concern Nigeria.

\begin{tabular}{|c|c|c|c|c|c|c|c|}
\hline & 2005 & 2006 & 2007 & 2008 & 2009 & 2010 & 2011 \\
\hline $\begin{array}{l}\text { Greenhouse gas emissions (GHGs) } \\
\text { (million tonnes } \mathrm{CO}_{2} \text { equivalent) }\end{array}$ & 93 & 88 & 82 & 75 & 69 & 76 & 74 \\
\hline Flaring [B] & & & & & & & \\
\hline Nigeria & 5.8 & 3.7 & 2.5 & 2.3 & 1.9 & 2.4 & 2.0 \\
\hline Rest of world & 1.2 & 1.1 & 0.9 & 0.5 & 0.7 & 1.2 & 1.4 \\
\hline $\begin{array}{l}\text { Energy intensity } \\
\text { Refinery Energy index }\end{array}$ & 95.8 & 92.5 & 92.6 & 93.0 & 92.0 & 89.3 & 90.8 \\
\hline $\begin{array}{l}\text { Acid gases and VOCs } \\
\text { VOCs (1000 tonnes) }\end{array}$ & 199 & 185 & 148 & 130 & 126 & 133 & 111 \\
\hline $\begin{array}{l}\text { Ozone layer-depleting emissions } \\
\text { Hydrochlorofluorocarbons (tonnes) }\end{array}$ & 35 & 35 & 27 & 26 & 24 & 21 & 11 \\
\hline $\begin{array}{l}\text { Oil spills and discharges } \\
\text { Nigeria - vol. (thousand tonnes) }\end{array}$ & & & & & & & \\
\hline Sabotage & 1.5 & 1.3 & 2.7 & 6.5 & 14.0 & 3.0 & 1.6 \\
\hline Operations & 0.1 & 1.4 & 1.6 & 7.1 & 0.3 & 0.7 & 5.3 \\
\hline Rest of world & 3.3 & 2.5 & 1.9 & 1.7 & 1.1 & 2.2 & 0.7 \\
\hline $\begin{array}{l}\text { Waste disposal } \\
\text { (thousand tonnes) }\end{array}$ & 1,263 & 1,870 & 2,806 & 1,684 & 2,101 & 2,000 & 2,477 \\
\hline
\end{tabular}

Figure 1: Environmental Data (Source: Shell Sustainability Report, 2011)

There is quite a good development in direct greenhouse gas emissions for some period of years, but experience an increment of about $10 \%$ in 2010 . This is as a result of business expansion. The $3 \%$ reduction in 
2011 is attributed to downsizing in production in some of its downstream in other part of the world, and reduction in gas flares in Nigeria(Shell Report, 2011).

The operational spills in Nigeria have no significant environmental improvement over the years, and have contributedto the volume of global operational spills in Shell. It claims that $72 \%$ volume of the spills is fromsabotage and theft, and the remaining percentage is due to its own operational failures and ageing facilities; but its 2011 report shows an outrageous oil spill due to its operations over the sabotage spill.

In the area of waste disposal the peak in 2007 has significantly declined in 2008 due to work abandonment at a downstream location in 2007 (shell Report, 2008). Overall increase in total waste disposal is also attributed to business growth

Gas flaring has progressively decline for seven years in Nigeria, which also impacts the overall reduction in gas flaring in Shell generally. This is due to cutting down the production in response to OPEC Quotas, and equipment efficiencies (Shell Report, 2005).

There is an improving environmental performance in the areas of Acid gases and VOCs, and ozonedepleting emissions over the years. This could be attributed to reduced gas flaring.

\section{Social Performance:}

The components that are measured to evaluate Shell's social performance for seven years are presented as data in Table 2 below. It covers many indicators under work force protections; product safety and environmental risks; process safety; local community and society; human rights; business morals and transparency; labour practice. This data comprises combined elements of entire shell performance; Shell Nigeria not reported separately, and so very few are reflected in this write up.

\begin{tabular}{|c|c|c|c|c|c|c|c|}
\hline & 2005 & 2006 & 2007 & 2008 & 2009 & 2010 & 2011 \\
\hline Fatalities & & & & & & & \\
\hline Total number & 34 & 37 & 21 & 26 & 20 & 12 & 6 \\
\hline Injuries & & & & & & & \\
\hline Total recordable case frequency (TRCF) & 2.5 & 2.1 & 1.9 & 1.8 & 1.4 & 1.23 & 1.24 \\
\hline $\begin{array}{l}\text { Illnesses } \\
\text { Total recordable occupational illness frequency }\end{array}$ & 2.0 & 1.8 & 1.5 & 1.2 & 0.6 & 0.76 & 0.66 \\
\hline $\begin{array}{l}\text { Social investment } \\
\text { (\$ million) }\end{array}$ & 127 & 140 & 170 & 148 & 132 & 121 & 125 \\
\hline
\end{tabular}

Figure 2: Social Data (Source: Shell Sustainability Report, 2011)

In the overall, the social data over the years reveals that Shell is making a reasonable progress in the area of social performance, and expresses their commitment to respect human rights. The 2011 Report states that the company achieved some progress in terms of community empowerment, health care support, and boosting community electricity supply and Nigeria's economy.

\section{Progress and Barrier:}

In the analysis of the sustainability performance of Shell's operation in Nigeria for seven years, there is quite a remarkable progress in the area of social performance, and fairly in the environmental performance (gas flaring, Green House Gas emissions, ozone-depleting emissions, Acid gasses and VOCs).

While Shell is making quite a good progress in social and environmental performance, challenges and worries continue, mostly in the areas of spills to the environment, and security in Nigeria. Climate change (indicators: flared gas, energy use, and Greenhouse gas (GHG) emissions) is yet another dilemma in global shell.

Limitations in the area of oil spills from oil installations is a result of third party interference (theft and sabotage) which accounted for $74 \%$ of the spills; while the rest is as a result of failures in operations such as equipment failures and human errors (Shell Nigeria, 2012). The poor performance on employee safety is primarily due to kidnapping and armed attack on the employee which results from Shell's inability to resolve conflicts generated as a result of its operations in the local communities.

Another barrier is that Niger Delta Nigeria is rich in resource therefore corruption levels are high and this has translated to political instability and poor governance and hence, resource overburden.

\section{Catalysts for Change, and Obstacles}

\section{Catalysts for Change}

The strategies chose by oil industry towards sustainable development influences its reputation, which consequently will build up some level of trust and legitimacy that will be accorded by the society.

Public consciousness is on the increase as regards the environment harm and community negligent that results from the operations of oil companies, and so the companies are often criticized. 
There is pressure of competition among multinational companies over their accessibility to many of the world's oil resources.

Shell having had a number of controversial issues previously that drew international attention, the event of Brent Spar case in 1995 and others like Ogoni crisis in Nigeria, they now want to live up to expectations and take sustainability issue with every seriousness it deserves.

Global drivers of sustainability (Legislations, investors, and other stakeholders like NGO) are also catalysts for change:

Shell (2011) realises that focussing on sustainable development will add value to its business, attract stakeholders, and reduce risk in its operations and finances. This is integral to its brand, future growth and profitability.

Maintenance of social licence to operate.

The company would want to avoid the financial burden involved in environmental clean-up, for example, oil spills.

Reduction of waste contributes to profit as waste is a cost; e.g, gas can be processed and sold instead of flaring.

\section{Obstacles to Integration of Sustainable Development in Policy}

Prevailing short-term perspectives: this leads to ignoring the future in terms of economic, politics, and psychology. This does not only make the company to ignore the distant future generation but also the near future of the present generation.

Lack of vision with regard to the possible consequences of continuing unsustainable development parts, and this makes it difficult to appreciate the connection between the present behaviour and the future conditions and the relationships between different types of human pressures on the environment (Baker, 1997).

Lack of capacity (economic, technical, scientific, even administrative capacity).

Difficulties of handling distributive issues within the sector, social groups, communities; can create conflicts that jeopardize the very idea of sustainable development and the possibility of integration.

No political will to effectively create change; no commitment to the feature, poverty alleviation, equity, etc.

Fear of accepting extra social and environmental responsibility that is not justifiable by business priorities in poorly-governed developing countries.

Too much concern for business turnover. This makes the company to be environmentally sensitive rather than sustainable development which includes a systemic concern for poverty and the environment (Viederman, 1997).

\section{Obstacles to Performance}

Greater percentage of oil spill in Niger Delta Nigeria is caused by oil theft and sabotage.

Oil spill sites are not easily accessed by Shell to be able to carry out investigations, clean-up and remediation in good time. They are denied access by some armed groups of people who are angry at the spills and its implications on the environment while some persons bargaining for clean-up contracts and/or to be compensated for the damage (Shell in Nigeria, 2012).

Corrupt leadership of the community heads, and at the same time being particularly exposed to consumer actions in its activities, requires a balancing act that Shell has not always manage (Tangen, 2003).

No creation of a comfortable level playing ground by the government and taking of steps that would berobust and got economic feasibility, even with Shell's proactivity towards sustainable development in Niger Delta Nigeria.

Absence of institutional experience to operate all the mechanism of democratic system has been battling and frustrating sustainability performance in Nigeria.

In spite of Shell's huge funds sunk in community affairs in this Niger Delta area the view of the angered Ogoni people towards Shell has not changed, ever since the killing of Ken Saro-Wiwa (Boele et al., 2001)

\section{Conclusion}

This essay considers the progress and barriers in relation to Sustainable Development of Shell oil and gas industry, with a particular attention on the Shell Nigeria where it has been operating for over 50 years among the Niger Delta community. The catalyst for change, the obstacles to integration of sustainable development in policy, and obstacle to performance were discussed.

Despite Shell's good progress, as expressed in their annual sustainability reports, there still exist some challenges particularly in the areas of oil spills, gas flaring and security in the Niger Delta.

The general approach of Shell indicates that it understands sustainability issues fronting it and the actions required to improve sustainable performance. Shell also realises its duty in confronting this matters and has put in place mechanisms internally and externally for accountability. So far, its previous approaches and 
current controversial issues do not underpin its communicated efforts. Shell's failure to resolve major controversies surrounds its Nigeria industrial activities has marred its struggles to improving its social and environmental performance, and thus, affected its reputation and also reduced trust from society.

Consistency does not exist between corporate management and local management and operational behaviour. So communicated approach at global level and its local operational behaviour towards sustainable development has to be consistent and more aligned to win reputation, legitimacy and trust from society.

Finally, Shell is encouraged to target long-term performance in sustainable development that is robust across economic, social, environmental and political spheres in Nigeria.

\section{References}

[1]. Albert, K.(2011). Royal Dutch Shell and its sustainability troubles. Background report to theErratum of Shell's Annual Report 2010 [online]. [Accessed 12/03/2013]. Availablefrom: www.milieudefensie.nl/publicaties/rapporten/shell-background-report

[2]. About GRI, Global Reporting Initiative. (2013).[online]. [Accessed 22/03/2013]. Availablefrom: www.globalreporting.org

[3]. Baker, S. (1997).The Politics of Sustainable Development: Theory, Policy and Practice within the European Union. London: Routledge, P.121.

[4]. Barry, D. \&Bass, S.(2002). Sustainable Development Strategies: A resource Book.Organisation for Economic Co-operation and Development, Paris and United Nations Development Programme, UNDP. London:Earthscan, pp. 2-15.

[5]. Boele, R., Fabig, H.\& Wheeler, D. (2001).Shell, Nigeria and the Ogoni. A study in unsustainable development: II. Corporate social responsibility and 'stakeholder management' versus a right-based approach to sustainable development. Sustainable Development, 9, 121-135. [Accessed 18/03/2013]. Available from:http://www.people.fas.harvard.edu/ hiscox/BoelETAL.pdf

[6]. Friends of the Earth International, FOEI (2011). Friends of the Earth International call for Shell to be held to Account [online]. [Accessed 12/03/2013].Available from:www.foei.org/.../2011/friends-of-the-earth-international-call-for-shell...

[7]. Frynas, J. G. (2009). Beyond corporate social responsibility: oil Multinationals and Social Challenges.. New York: Cambridge University Press, p. 207.

[8]. IPIECA, API, OGP. (2010). Oil and gas industry guidance on voluntary sustainability Reporting [online], $2^{\text {nd }}$ Edition.[Accessed 22/03/2013]. Available from:www.api.org/.../voluntary_sustainability_reporting_guidance_2010.a...

[9]. Jenkins, R. (2005). Globalization, corporate social responsibility and poverty. International Affairs [online], volume 81, issue 3, pp.525-40. May 2005. [Accessed 22/03/2013]. Available from:DOI: 10.1111/j.1468-2346.2005.00467.x

[10]. Lyn, A. (2003). HSE Horizons: Sustainable Development in Oil and Gas Industry. Exploration and ProductionEnvironmental Conference [online].SPE/EPA/DOE. San Antonio, Texas, 10-12 March 2003. [Accessed 22/03/2013]. Available from:www.spe.org/jpt/print/archives/2003/...JPT2003_08_hse_horizons.p...

[11]. Lyuba, Z. (2005). International Investment for Sustainable Development: Balancing Rights and Rewards. London: Earthscan, p. 200

[12]. Naimi, A. (2011). Sustainability Issues in the Petroleum Refining Industry: A Case Study of Shell.Otago Management Graduate $\begin{array}{lllll}\text { Review } & \text { [online].Vol. } & \text { 9. [Accessed } & \text { 22/03/2013] }\end{array}$ www.business.otago.ac.nz/mgmt/publications/omgr/.../11 naimi.pdf

[13]. Sachs, J. D. \& Warner, A. M. (1999). The Big Push, Natural Resources Boomsand Growth. Journal of Development Economics $\begin{array}{lllll}\text { [online]. } & \text { Vol.59, } & \text { [Accessed } & \text { 22/03/2013]. }\end{array}$ from:www.earth.columbia.edu/sitefiles/file/about/.../JnlofDevtEcon1999.p...

[14]. Shell (2011). Shell Sustainability Reports (2011 Report and Past Reports) [online].[Accessed 18/03/2013]. Available from:www.shell.com > Environment \& Society > Sustainability reporting

[15]. Shell Dialogues (2011). Shell in Nigeria - working in a complex environment [online].[Accessed 18/03/2013]. Available from:www.shelldialogues.com/.../Nigeria\%20Webchat $\% 20-\% 20 \mathrm{July} \% 202 .$.

[16]. Shell in Nigeria (2012). Environmental Performance-Oil Spills [online].[Accessed 18/03/2013]. Available from:s09.staticshell.com/content/dam/shell/static/.../env-perf-oilspills.pdf

[17]. Sustainable Development Commission (2011). What is Sustainable Development [online].[Accessed 18/03/2013]. Available from:www.sd-commission.org.uk/

[18]. Shell International (1995). Shell reverses decision to dump the Brent Spar[Accessed 18/03/2013]. Available from:www.greenpeace.org > ... > History and Successes > Victories timeline

[19]. Tangen, K. (2003). Shell: Struggling to Build a Better World? FNI (THE FRIDTJOF NANSEN INSTITUTE) Report [online]. 1/2003[Accessed 18/03/2013]. Available from:www.fni.no/doc\&pdf/FNI-R0103.pdf

[20]. UNGCA, UN Global Compact and Accenture. (2012). Sustainable Energy for All: Opportunities for the Oil and Gas Industry [online]. [Accessed 18/03/2013]. Available from:www.unglobalcompact.org/docs/issues_doc/.../12SEFA_Oil_Gas.pdf

[21]. Viederman, S. (1997). Multinational Corporations are Incompatible with Sustainable Development.Global Policy Forum: United Nations Correspondents Association [online].June 23, 1997.[Accessed 18/03/2013]. Available from:www.globalpolicy.org/social-and-economic-policy/.../45488.html

[22]. Wheeler, D., Sutherland, N., \& Kelly, N. (2000). Corporate strategy and sustainability in business: A North American review. Proc ERPEnvironment Conference on Eco-Management and Auditing, Manchester.

[23]. World Commission on Environment and Development, WCED. (1987). Our Common Future, Oxford University Press, Oxford.Pp 8-46 